\title{
Correlation of CA-125 with different stages of endometriosis
}

\author{
Runa Laila, Begum Nasrin, Shayela Shamim and Md. Mozammel Hoque
}

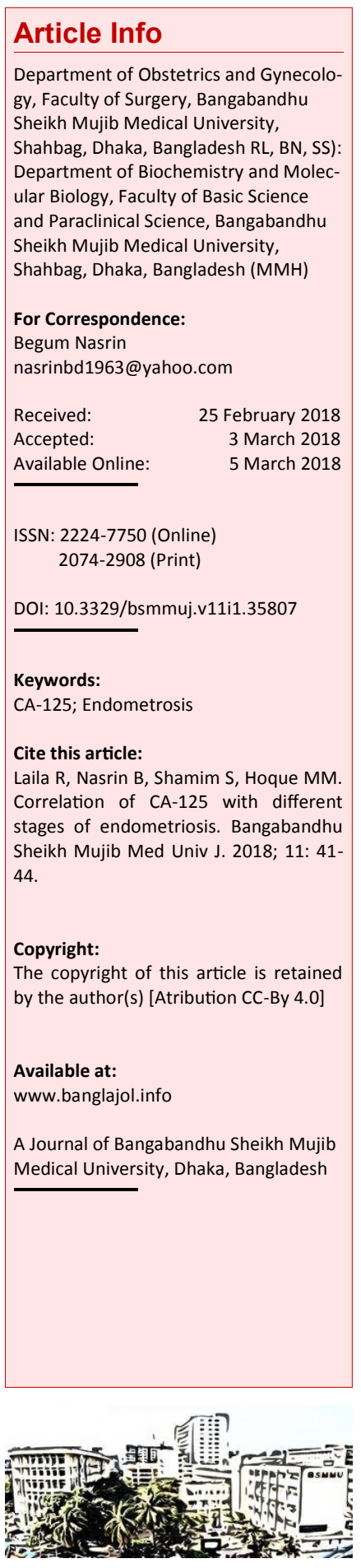

\begin{abstract}
This study was conducted to evaluate the association of serum cancer antigen (CA-125) level with the severity of pelvic endometriosis. Seventy diagnosed cases of pelvic endometriosis were included in this study. The CA-125 level was estimated in all these patients, cutoff value of the serum CA-125 level was considered $35.0 \mathrm{U} / \mathrm{mL}$. The correlations between serum CA-125 and different stages of endometriosis were evaluated by linear regression analysis. In Stage I of endometriosis, the mean serum CA-125 level was $21.8 \pm 15.1 \mathrm{U} / \mathrm{mL}$, in Stage II $26.0 \pm 17.3 \mathrm{U} / \mathrm{mL}$, in Stage III $83.2 \pm 48.9 \mathrm{U} / \mathrm{mL}$ and in Stage IV $117.0 \pm 41.6 \mathrm{U} / \mathrm{mL}$. A significant positive correlation $(r=0.729 ; p=0.001)$ was found between the serum CA-125 and different stages of endometriosis.
\end{abstract}

\section{Introduction}

Endometriosis is an estrogen-dependent condition and mostly affects women in their reproductive age. The prevalence rate of this disease in infertile women is about $20-50 \%$ but it can be as high as $80 \%$ in women who suffer from chronic pelvic pain. $\underline{1-3}$ A survey report from multicentric tertiary level infertility care hospitals of Bangladesh shows that patients seeking treatment for infertility, $9.6 \%$ suffer from endometriosis. .4

The pathophysiology of endometriosis is not well understood. Different theories attempted to explain this disease, although none of them have been entirely proven. Most accepted theory include endometriotic implants that are derived from the metaplasia of coelomic epithelium. It is likely that the combination of various factors can cause and determine the severity of this disease.

Many researchers worked on the cancer antigen (Ca-125) to evaluate its sensitivity for the diagnosis of endometriosis but the results were disappointing in minimal and mild disease.

But Ca-125 level was significantly higher in women having moderate and severe endometriosis..-11

Basically Ca-125 is a cancer biomarker used for monitoring and follow-up of the ovarian cancer following definitive surgery and chemotherapy and to detect early recurrence. $\underline{12-14}$

One study shows that the serum CA-125 level was raised in patients having endometriosis and there was a positive correlation between the Ca-125 level and the advanced stages of the disease. 15 Thus, the clinical value of serum CA125 level was studied extensively in the diagnosis of endometriosis.

Some studies have reported that serum CA-125 levels were reduced after surgery of endometriosis followed by medical treatment. Other investigators have shown that the measurement of serum CA-125 was more useful for monitoring the patients who were treated medically than in the diagnosis of the disease.20-21 Study shows that serum CA-125 levels raised during menstruation about three times than those before menstruation in women suffering from endometriosis. $\underline{22}$

This study was done with the aim to measure the serum CA-125 for the diagnosis and also to evaluate the severity of endometriosis.

\section{Materials and Methods}

It is a cross-sectional comparative study. This study was carried out during the period of January 2013 to August 2014. Seventy diagnosed cases of pelvic and ovarian endometriosis were included in this study. Women with the ovarian malignancy established by intraoperative findings or histopathology, fibroid, adenomyosis, pelvic inflammatory disease, or any other malignancy were excluded from the study. All the study subjects were classified into 4 stages according to the revised American Fertility Society Classification. The purpose of this research work was explained elaborately to the patient who fulfilled the enrollment criteria 
and informed written consent was taken from all participants of this study. Pre-tested case record form was used to collect the relevant demographic, clinical findings and investigation reports.

Five milliliter of blood sample was drawn from the antecubital vein of each patient with endometriosis. Then the blood sample was centrifuge for $5 \mathrm{~min}$ at a rate of $3,000 \mathrm{rpm}$ at $4^{\circ} \mathrm{C}$ and the supernatant was stored at $-70^{\circ} \mathrm{C}$ until analysis. The serum was not allow to be thawed until the assay was performed.

Serum CA-125 level was measured by IMMULITE 2000 OM-MA (SIEMENS, USA) and was expressed in arbitrary units based on a primary reference standard. This study was choosing $35.0 \mathrm{U} / \mathrm{mL}$ as the cutoff value of the serum CA-125 level.

Data were collected from the patient on variables of interest by interview, clinical examination, operative findings, hematological investigations, histopathological report and from the history sheet of the patient.

\section{Data analysis}

All data were analyzed using Statistical Package for Social Sciences (SPSS), Windows (version 20.0; USA) and Epi info (version 1.0.3, USD, Stone Mountain, GA). Categorical variables were presented in the form of mean and standard deviation. Statistical difference between the mean CA-125 levels in various groups of endometriosis was obtained from ANOVA test. The $p$ value of $<0.05$ was considered statistically significant. Linear regression analysis was done to evaluate the correlation of serum CA-125 with different stages of endometriosis.

\section{Results}

In this study, it was observed that majority $(80.0 \%)$ of the patients had dysmenorrhea, $54.3 \%$ subfertility, $51.4 \%$ lower abdominal pain, $17.1 \%$ lump in the lower abdomen, $15.7 \%$ dyspareunia, and $14.3 \%$ had menorrhagia (Table I). Regarding CA-125, almost three-fourth $(74.3 \%)$ of the patients had the level of $>35.0 \mathrm{U} / \mathrm{mL}$ and $25.7 \%$ had $\leq 35.0 \mathrm{U} / \mathrm{mL}$. The mean ( \pm SD) serum CA-125 was found $81.1 \pm 54.6 \mathrm{U} / \mathrm{mL}$ with range from 5.1 to $197 \mathrm{U} / \mathrm{mL}$. Almost half (32) of the patients were in Stage IV of endometriosis, 17 in Stage III, 14 in Stage II and 7 in Stage I (Table II). Table II shows the serum CA-125 level in different stages of endometriosis among the study subjects. It was observed that in Stage I, the mean $( \pm S D)$ of CA -125 level was $21.8 \pm 15.1 \mathrm{U} / \mathrm{mL}$, in Stage II it was $26.0 \pm 17.3 \mathrm{U} / \mathrm{mL}$, in Stage III $83.2 \pm 48.9 \mathrm{U} / \mathrm{mL}$ and in Stage IV $117.0 \pm 41.6 \mathrm{U} / \mathrm{mL}$. The difference was statistically significant $(\mathrm{p}<0.05)$ among four groups. A significant positive correlation (Spearman correlation coefficient $r=0.729 ; \quad p=0.001$ ) was found

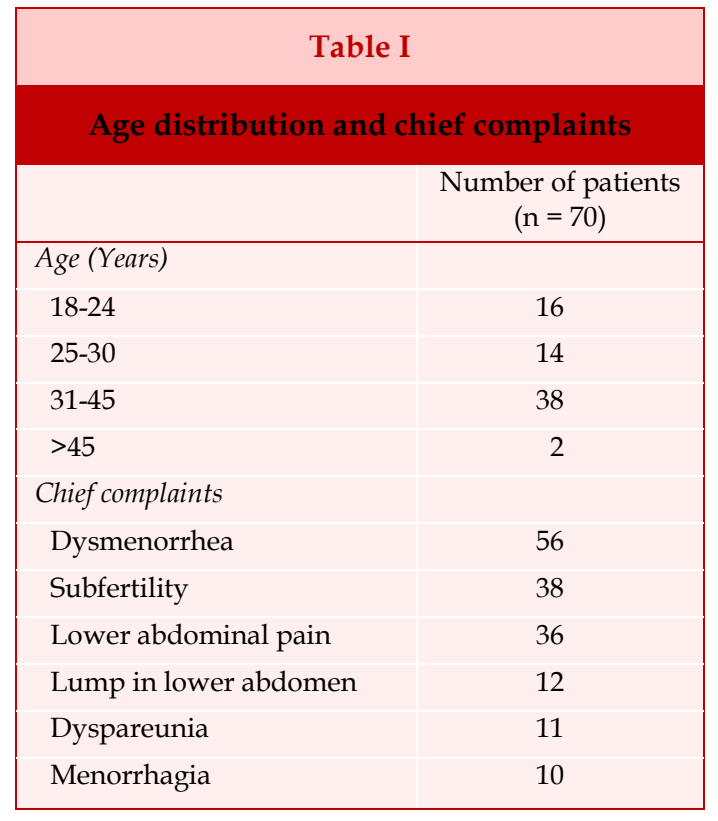

\begin{tabular}{|c|c|c|}
\hline \multicolumn{3}{|c|}{ Table II } \\
\hline \multicolumn{3}{|c|}{$\begin{array}{c}\text { Serum CA-125 levels in different stage of } \\
\text { endometriosis }\end{array}$} \\
\hline $\begin{array}{l}\text { Stage of } \\
\text { endometriosis }\end{array}$ & $\mathrm{n}$ & $\begin{array}{r}\mathrm{CA}-125 \\
(\text { mean } \pm \mathrm{SD})\end{array}$ \\
\hline Stage I & 7 & $21.8 \pm 15.1$ \\
\hline Stage II & 14 & $26.0 \pm 17.3$ \\
\hline Stage III & 17 & $83.2 \pm 48.9$ \\
\hline Stage IV & 32 & $117.0 \pm 41.6$ \\
\hline
\end{tabular}

between the CA-125 and different stage of endometriosis (Figure 1).

\section{Discussion}

In this current study, it was observed that the serum CA-125 level was $>35.0 \mathrm{U} / \mathrm{mL}$ in almost threefourth of the patients and whereas in $25.7 \%$ of the patients the level was $\leq 35.0 \mathrm{U} / \mathrm{mL}$ and the mean CA-125 was found $81.1 \pm 54.6 \mathrm{U} / \mathrm{mL}$ varied from 5.08 to $197 \mathrm{U} / \mathrm{mL}$. Similarly, Kurdoglu et al. (2009) showed $48.0 \%$ participants had serum CA 125 level of $>5.0 \mathrm{IU} / \mathrm{mL} . \underline{2}$ In another study, Szubert et al. (2012) found that the mean value of serum CA-125 in the endometriosis group was $34.0 \mathrm{U} / \mathrm{mL}$ whereas mean value of CA-125 in peritoneal fluid was 1241.9 $\mathrm{U} / \mathrm{mL} .24$ Amaral and colleagues (2006) showed that in the endometriosis group, the serum CA-125 level was raised than those of the control group during menstration. $\underline{25}$ Ramos et al. (2012) reported that the CA-125 serum level was significantly raised in women having infertility due to endometriosis than those who were fertile and who never tried.26 In the current study, the mean CA-125 according to 


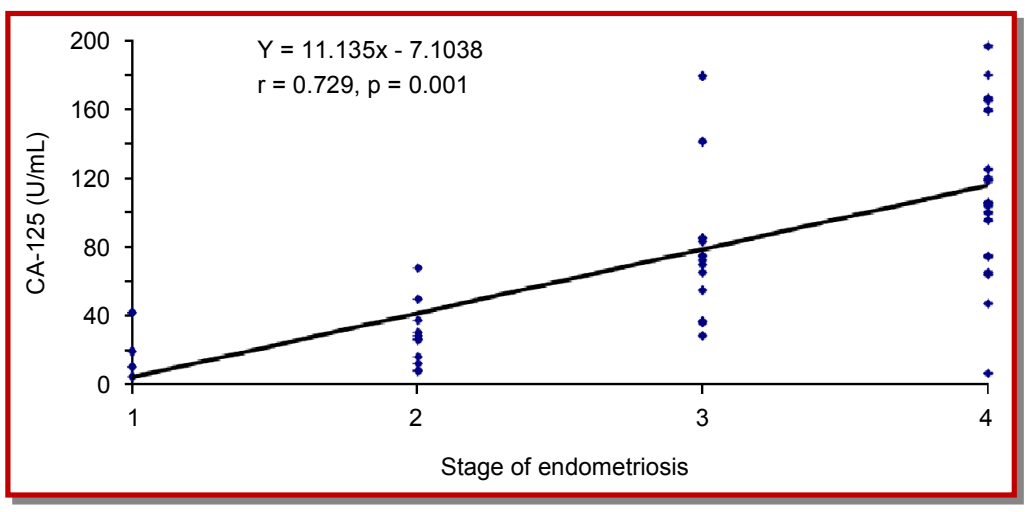

Figure 1: Scatter diagram showing a significant positive correlation (Spearman correlation coefficient $\mathrm{r}=0.729 ; \mathrm{p}=0.001$ ) was found between CA-125 according to different stage of endometriosis

different stage of endometriosis was found $21.8 \pm$ $15.1 \mathrm{U} / \mathrm{mL}$ in Stage I, in Stage II it was $26.0 \pm 17.3$ $\mathrm{U} / \mathrm{mL}$, in Stage III it was $83.2 \pm 48.9 \mathrm{U} / \mathrm{mL}$ and in Stage IV $117.0 \pm 41.6 \mathrm{U} / \mathrm{mL}$. In this study, it was observed that the serum CA-125 level was increased with the grading of endometriosis. This finding is consistent with the findings from the other studies. $\underline{11,27-29}$ The mean CA-125 level was significantly $(p<0.05)$ elevated when compared between the different stages of endometriosis. Similarly, Somiglian et al. (2004) found that in Stage I-II, the mean CA-125 level was 13.3 with range from 9.223.0 U/mL. In Stage III-IV, the mean CA-125 level was 25.9 with range from 16.8 to $47.40 \mathrm{U} / \mathrm{mL}$. $30 \mathrm{In}$ another study, Kurdoglu et al. (2009) mentioned that the serum CA 125 level was not different among the patients having Stage I and II endometriosis but in patients with Stage III and IV endometriosis the level was remarkably higher. .33 In this series, it was observed that there was significant positive correlation $(r=0.729 ; p=0.001)$ between the CA-125 and different stage of endometriosis. Similar findings was observed by Szubert et al. (2012) where there was significant positive correlation between the stages of endometriosis and CA-125 level $(\mathrm{r}=0.599, \mathrm{p}<0.001) . \underline{24}$

\section{Conclusion}

The mean level of CA-125 was higher among the patients of endometriosis and the difference was statistically significant $(p<0.05)$ among the four groups. There was significant positive correlation between the different stages of endometriosis and serum CA-125.

\section{Ethical Issue}

The research protocol was approved by the Institutional Review Board (IRB) of Bangabandhu Sheikh Mujib Medical University.

\section{References}

1. Rawson JM. Prevalence of endometriosis in asymptomatic women. J Reprod Med. 1991; 36: 513-15.

2. Verkauf BS. Incidence, symptoms, and signs of endometriosis in fertile and infertile women. J Florida Med Assoc. 1987; 74: 671.

3. Carter JE. Combined hysteroscopic and laparoscopic findings in patients with chronic pelvic pain. J Am Assoc Gynecol Laparosc. 1994; 2: 43-47.

4. Fatima P, Ishrat S, Rahman D, Banu J, Deeba F, Begum N, Anwary SA, Hossain HB. Quality and quantity of infertility care in Bangladesh. Mymensingh Med J. 2015; 24: 70-73.

5. Buchweitz O, Poel T, Diedrich K, Malik E. The diagnostic dilemma of minimal and mild endometriosis under routine conditions. J Am Assoc Gynecol Laparosc. 2003; 10: 85-89.

6. Fedele LU, Arcaini L, Vercellini P, Marchini M, Baglioni A, Bianchi S. Serum Ca-125 concentrations in endometriosis. Acta Eur Fertil. 1989; 20: 137-39.

7. Barbieri RL, Niloff JM, Bast RC, Schaetzl E, Kistner RW, Knapp RC. Elevated serum concentrations of CA-125 in patients with advanced endometriosis. Fertil Steril. 1986; 45: 630-34.

8. Hornstein MD, Thomas PP, Gleason RE, Barbieri RL. Menstrual cyclicity of CA-125 in patients with endometriosis. Fertil Steril. 1992; 58: 279-83.

9. Pittaway DE, Rondinone D, Miller KA, Barnes K. Clinical evaluation of CA-125 concentrations as a prognostic factor for pregnancy in infertile women with surgically treated endometriosis. Fertil Steril. 1995; 64: 321-24.

10. Koninckx PR, Meuleman C, Oosterlynck D, Cornillie FJ. Diagnosis of deep endometriosis by clinical examination during menstruation and plasma CA-125 concentration. Fertil Steril. 1996; 65: 28087.

11. Cheng YM, Wang ST, Chou CY. Serum CA-125 in preoperative patients at high-risk for endometriosis. Obstet Gynecol. 2002; 99: 375-80.

12. Jiang T, Huang L, Zhang S. Preoperative serum CA125: A useful marker for surgical management of endometrial cancer. BMC Cancer. 2015; 15: 396.

13. Hossain F, Karim MN, Rahman SMM, Khan N, Siddiqui M, Hussain R. Preoperative detection of ovarian cancer by color doppler ultrasonography and CA 125. Bangladesh Med Res Counc Bull. 2010; 36: 68-73

14. Siddiqua SF, Chowdhury TA, Hai MA, Akhter PS, Rahman MA. Correlation between Ca125 and ovarian cancer: Bangladesh perspective. Med Sci Res. 2005; 5: 8-12

15. Hornstein MD, Harlow BL, Thomas PP, Check JH. Endometriosis: Use of a new CA 125 assay in the 
diagnosis of endometriosis. Hum Reprod. 1995; 10: 932-34.

16. O'shaughnessy A, Check JH, Nowroozi KO, Lurie DE. CA 125 levels measured in different phases of the menstrual cycle in screening for endometriosis. Obstet Gynecol. 1993; 81: 99-103.

17. Hornstein MD, Thomas PP, Gleason RE, Barbieri RL. Menstrual cyclicity of CA-125 in patients with endometriosis. Fertil Steril. 1992; 58: 279-83.

18. Koninckx PR, Riittinen L, Seppala M, Cornillie FJ. CA-125 and placental protein 14 concentrations in plasma and peritoneal fluid of women with deeply infiltrating pelvic endometriosis. Fertil Steril. 1992; 57: 523-30.

19. Mol BW, Bayram N, Lijmer JG, Wiegerinck MA, Bongers MY, van der Veen F, Bossuyt PM. The performance of CA-125 measurement in the detection of endometriosis: A meta-analysis. Fertil Steril. 1998; 70: 1101-08.

20. Chen FP, Soong YK, Lee N, Lo SK. The use of serum CA-125 as a marker for endometriosis in patients with dysmenorrhea for monitoring therapy and for recurrence of endometriosis. Acta Obstet Gynecol Scand. 1998; 77: 665-70.

21. Jacobs I, Bast RCJr. The CA 125 tumour-associated antigen: A review of the literature. Hum Reprod. 1989; 4: 1-12.

22. Pittaway DE, Fayez JA. Serum CA-125 antigen levels increase during menses. Am J Obstet Gynecol. 1987; 156: 75-76.

23. Kurdoglu Z, Gursoy R, Kurdoglu M, Erdem M, Erdem O, Erdem A. Comparison of the clinical value of CA 19-9 versus CA 125 for the diagnosis of endometriosis. Fertil Steril. 2009; 92: 1761-63.
24. Szubert M, Suzin J, Wierzbowski T, KowalczykAmico K. CA-125 concentration in serum and peritoneal fluid in patients with endometriosispreliminary results. Arch Med Sci. 2012; 8: 504-08.

25. Amaral VF, Ferriani RA, Sá MF, Nogueira AA, Silva AC, Moura MD. Positive correlation between serum and peritoneal fluid CA-125 levels in women with pelvic endometriosis. Sao Paulo Med J. 2006; 124: 223-27.

26. Ramos I, Podgaec S, Abrão M, Oliveira R, Baracat E. Evaluation of CA-125 and soluble CD-23 in patients with pelvic endometriosis: A case-control study. Rev Ass Méd Bras. 2012; 58: 26-32.

27. Pittaway DE, Fayez JA. The use of CA-125 in the diagnosis and management of endometriosis. Fertil Steril. 1986; 46: 790-95.

28. Koninckx PR, Meuleman C, Oosterlynck D, Cornillie FJ. Diagnosis of deep endometriosis by clinical examination during menstruation and plasma CA-125 concentration. Fertil Steril. 1996; 65: 280-87.

29. Medl M, Ogris E, Peters-Engl C, Mierau M, Buxbaum P, Leodolter S. Serum levels of the tumourassociated trypsin inhibitor in patients with endometriosis. Brit J Obstet Gynaecol. 1997; 104: 78-81.

30. Somigliana E, Vigano P, Tirelli AS, Felicetta I, Torresani E, Vignali M, Di Blasio AM. Use of the concomitant serum dosage of CA 125, CA 19-9 and interleukin- 6 to detect the presence of endometriosis. Results from a series of reproducetive age women undergoing laparoscopic surgery for benign Gynaecological conditions. Hum Reprod. 2004; 19: 1871-76. 